\title{
Utility of dual time point 18 FDG PET-CT
}

\author{
SE De Luca*, JE Codas Thompson, E Casalini Vañek, H Campanelli, C Carrera, EP Eyheremendy \\ From International Cancer Imaging Society (ICIS) 14th Annual Teaching Course \\ Heidelberg, Germany. 9-11 October 2014
}

The Standardized Uptake Value (SUV) from FDG PET-CT is a simplified quantitative measure used for characterization of tissues suspected for malignancy. Its rationale is based in augmented glucose consumption of oncologic cells although, many other benign pathologies, could show elevated values leading to error.

The purpose of this presentation is to demonstrate that SUV value continues elevating in malignant pathology while in benign disease will decrease over time.

We prospectively acquired delayed images in patients with focal increase of metabolic activity without clear morphologic pathology, or failing to show increase metabolic activity in sites with morphological findings of probable oncologic origin. We have acquired delayed evaluation in 45 patients with suspicious lesions.

The most prominent findings were: 11 patients with focal hypermetabolic sites in gastrointestinal tract who demonstrate significant SUV decline on delayed images, avoiding unnecessary colonoscopies, while another 17 patients have significantly increased SUV on delayed images, correlated with polypoid lesions at colonoscopy. 7 patients with falling SUV on delayed images in adnexal hypermetabolic foci proved to be of functional origin at ultrasound follow-up, 5 patients with descending SUV at delayed images in hypermetabolic foci in the neck proved to be inflammatory on follow-up and 5 patients that SUV value continues elevating on delayed images, secondary or primary origin was confirmed.

Dual time point PET-CT has proven to be an important tool for proper characterization of questionable lesions that would lead to costly mistakes or unnecessary diagnostic studies.
Published: 9 October 2014

doi:10.1186/1470-7330-14-S1-P24

Cite this article as: De Luca et al:: Utility of dual time point 18 FDG PETCT. Cancer Imaging 2014 14(Suppl 1):P24.

\footnotetext{
* Correspondence: sdeluca@hospitalaleman.com Hospital Alemán, Buenos Aires, Argentina
}

Submit your next manuscript to BioMed Central and take full advantage of:

- Convenient online submission

- Thorough peer review

- No space constraints or color figure charges

- Immediate publication on acceptance

- Inclusion in PubMed, CAS, Scopus and Google Scholar

- Research which is freely available for redistribution

Submit your manuscript at www.biomedcentral.com/submit
() Biomed Central
C Biomed Central

(c) 2014 De Luca et al; licensee BioMed Central Ltd. This is an Open Access article distributed under the terms of the Creative Commons Attribution License (http://creativecommons.org/licenses/by/4.0), which permits unrestricted use, distribution, and reproduction in any medium, provided the original work is properly cited. The Creative Commons Public Domain Dedication waiver (http://creativecommons.org/publicdomain/zero/1.0/) applies to the data made available in this article, unless otherwise stated. 